\title{
Phosphorus behavior on an Oxisol fertilized by phosphate alkaline biosolid and cultivated with common bean ${ }^{1}$
}

\author{
Luiz C. da Silva ${ }^{2}$, Luiz A. C. Lucchesi ${ }^{3}$, Henrique S. Koehler ${ }^{4} \&$ Milton C. C. Campos ${ }^{5}$
}

\begin{abstract}
A B STRACT
This study aimed to evaluate the extractable phosphorus Mehlich-1 in a distrophic Red-Yellow Latosol (Oxisol) which received alkaline sewage sludge (alkaline biosolid) along with $0,0.436,0.872$ and 1.745 dag $\mathrm{kg}^{-1}$ of P from three different sources and cultivated with common bean (Phaseolus vulgaris Cv. IPR Uirapuru) in greenhouse. It also aimed to quantify the phosphorus uptake by the plant, plant production and the relative agronomic effectiveness index. For the establishment of the treatment the recommended dose was $45.85 \mathrm{~kg} \mathrm{ha}^{-1}$ of $P$ from the treatments, except the control ( $0 \mathrm{dag} \mathrm{kg}^{-1}$ of $\mathrm{P}$ ). This dose was calculated for $2.5 \mathrm{~kg}$ of this 0 xisol from Contenda, Paraná State, Brazil, contained in recepients of $3 \mathrm{dm}^{3}$ with 6 cultivated bean plants (cv. IPR Uirapuru). Phosphorus added in alkaline biosolid increased the extractable phosphorus (Mehlich-1) in soil and phosphorus accumulated in plants as well as the grain and total dry mass production of bean plants. The best level of phosphorus added to alkaline biosolid was 0.436 dag kg-1 $^{-1}$ of P from the partially acidulated phosphate rock Alvorada and single superphosphate.
\end{abstract}

Key words: phosphorus, dose, grains, dry mass, Phaseolus vulgaris

\section{Comportamento do fósforo em Latossolo fertilizado com biossólido alcalinizado fosfatado e cultivado com feijoeiro}

RESU M O

Propôs-se, com este trabalho, avaliar o fósforo extraível M ehlich-1 em um Latossolo Vermelho-Amarelo Distrófico típico, ácido, que recebeu lodo de esgoto alcalinizado (biossólido alcalinizado) adicionado com $0,0,436,0,872$ e $1,745 \mathrm{dag} \mathrm{kg}^{-1}$ de $\mathrm{P}$ proveniente de três diferentes fontes e cultivado com feijoeiro (Phaseolus vulgaris cv. IPR U irapuru) em casa de vegetação. O bjetivou-se, também, quantificar o fósforo acumulado pelas plantas, a produção das plantas e 0 índice de eficiência agronômica relativa. Para 0 estabelecimento de tratamentos a dose recomendada foi de $45,85 \mathrm{~kg} \mathrm{ha}^{-1}$ de $\mathrm{P}$ a partir dos tratamentos, exceto da testemunha ( 0 dag $\mathrm{kg}^{-1}$ de P). Esta dose de fósforo foi calculada para 2,5 kg deste Latossolo de Contenda, Paraná, contidos em vasos de $3 \mathrm{dm}^{3}$ cultivados com 6 plantas de feijoeiro (cv. IPR U irapuru). 0 fósforo adicionado em biossólido alcalinizado aumentou o fósforo extraível Mehlich-1 do solo, a acumulação de fósforo pelas plantas bem como a produção de grãos e a massa seca total das plantas de feijoeiro. 0 melhor nível de fósforo adicionado ao biossólido alcalinizado foi de $0,436 \mathrm{dag} \mathrm{kg}^{-1}$ de $\mathrm{P}$ proveniente de fosfato natural parcialmente acidulado Alvorada e superfosfato simples.

Palavras-chave: fósforo, dose, grãos, massa seca, Phaseolus vulgaris

${ }^{1}$ Part of the Dissertation in Soil Science of the first author presented at the Federal U niversity of Paraná State - UFPR

${ }^{2}$ Agronomist Ms, Scholarship of CAPES, Federal University of Amazon State, Campus Vale do Rio Madeira, Education, Agriculture and Environment Institute, IEAA. Rua 29 de Agosto, 786, Bairro Divino Pranto, Humaitá, AM, BR, 69750-000. Phone/Fax: (97) 33731180. E-mail: luiz_silva03@yahoo.com.br

3 Division of Agricultural Sciences: Soil Science and Agricultural Engineering Department of the Federal University of Paraná State (UFPR). Rua dos Funcionários, 1540, Juvevê, 80035-050, Curitiba, PR, BR. Phone/Fax: (41): 33505648. E-mail: Iclucche@ufpr.br

${ }^{4}$ Division of A gricultural Sciences: Phytotechnical and Phytosanity Department of the Federal University of Paraná State - UFPR Phone/Fax: (41) 33505648. E-mail: koehler@agrarias.ufpr.br

${ }^{5}$ Federal University of Amazon State, Campus Vale do Rio Madeira, Education, Agriculture and Environment Institute, IEAA. Rua 29 de Agosto, 786, Bairro Divino Pranto, Humaitá, AM, BR, 69750-000. Phone/Fax: (97) 33731180. E-mail: mcesarsolos@gmail.com 


\section{INTRODUCTION}

Among the most important environmental problems are the generation and disposal of sewage sludges. Currently, different forms of sewage sludge disposal have been verified. Among them are: incineration, the transformation in lightweight aggregate or bricks for civil construction and dumping in the oceans and in private or municipal landfills. The agricultural recycling of biosolids is an alternative to solve the problem, since they are soil conditioners suitable chemically, physically and biologically. This topic is regulated by a specific resolution of the National Environment Commission (CONAMA 375).

A portion of the sewage sludge generated in Curitiba, in 2001, was treated by the N-Viro Process, generating an alkaline sewage sludge called N-Viro Soil which is chemically, physically and biologically appropriate to this type of disposal. Since then, this product has been the subject of studies related to its potential use in agriculture. The process of treatment adds carbonates and oxides and, consequently, important nutrients like calcium $(\mathrm{Ca})$ and magnesium $(\mathrm{Mg})$ and a corrective potential of soil acidity conferred by these materials.

Considering these informations, the application of sewage sludges to agricultural soils can be a geochemically sustainable method to eliminate this urban problem. According to work developed by Logan \& Harrison (1995) these sewage sludges have organic matter, some macro and micronutrients in its composition besides alkaline reaction in acidic soils.

Several studies showed that the alkaline biosolids (Silva et al., 2010a; 2011) and phosphate fertilisers (Ostoics et al., 2005) alter the soil chemical characteristics which corroborate with the phosphorus increase in soils. Some authors also verified increases in the P absorption (Corrêa et al., 2004), extractable P Mehlich-1 (Silva et al., 2001; Gomes et al., 2005; Chueiri et al., 2007) and in the bean and corn (Lourenço et al., 1996; Nascimento et al., 2004) and just in the corn productivity (Silva et al., 2002), concomitantly to the increasing doses of sewage sludge (Guedes et al., 2006) or alkaline sewage sludge applied in the presence of inorganic phosphatic fertilizers or not (Silva et al., 2010; Vieira et al., 2005). Similar results were obtained by Bar-Tal et al. (2004) for wheat and Christie et al. (2001), for spring barley.

Single superphosphate (SSP), triple superphosphate (TSP) and partially acidulated rock phosphate (PAP) are the sources normally used for soil fertilization to supply $\mathrm{P}$ to the plants. The average content of $\mathrm{P}$ in alkaline biosolids is low. To meet the crop requirements large quantities of these biosolids must be applied to the soil which can excessively increase its $\mathrm{pH}$ and create a harmful atmosphere to the plant growth. The presence of other nutrients and the corrective potential of soil acidity of these materials can be a decisive factor in the choice of $\mathrm{P}$ sources by the farmers.
Consequently, the $\mathrm{P}$ added in alkaline biosolid from the different sources may be an additional factor to attract farmers to the use adequate quantities of these biosolids since this practice can reduce the costs with phosphate fertilizer and the liming operations of bean producers which are small and underfunded in Parana State, Brazil.

This study aimed to evaluate the extractable phosphorus Mehlich-1 in an Oxisol which received alkaline sewage sludge (alkaline biosolid) along with 0, 0.436, 0.872 and $1.745 \mathrm{dag} \mathrm{kg}^{-1}$ of $\mathrm{P}$ from three different sources and cultivated with common bean (Phaseolus vulgaris cv. IPR Uirapuru) in greenhouse. It also aimed to quantify the phosphorus uptake by the plant, plant production and the relative agronomic effectiveness index.

\section{MATERIAL AND METHODS}

The experiment was carried out from July through November, 2006, in the greenhouse of the Soil Science and Agricultural Engeneering Department of the Federal University of Paraná State, Curitiba-Paraná State, Brazil.

The first $20 \mathrm{~cm}$ of a clayey and distrophic Red-Yellow Latosol an Oxisol from Contenda, Paraná State, Brazil, was passed in a $2 \mathrm{~mm}$ sieve. The soil was collected in a never cultivated subtropical forest under secondary sucession and classified according to EMBRAPA (2006). Its initial physical and chemical characteristics are shown in the Table 1.

A sewage sludge from the Treatment Station Belém, Curitiba, Paraná State, Brazil, was treated by the N-Viro Process (advanced alkaline stabilization with subsequent accelerated drying process). The final product obtained was an alkaline sewage sludge called N-Viro Soil (alkaline biosolid) which was passed in a $4 \mathrm{~mm}$ sieve according to Brazilian Association of Technical Norms (ABNT). The agronomic characteristics of this alkaline biosolid according to Pavan et al. (1992) and Brasil (1988) are specified in the Table 2.

This alkaline biosolid was added in doses equivalent to 0 , $0.436,0.872$ and $1.745 \mathrm{dag} \mathrm{kg}^{-1}$ of $\mathrm{P}$ from the partially acidulated phosphate rock Alvorada (PAP), single superphosphate (SSP) and triple superphosphate (TSP) whose chemical characteristics are shown in the Table 3.

To establish the treatments a test dose of $45.85 \mathrm{~kg} \mathrm{ha}^{-1}$ of $\mathrm{P}$ (105 kg ha-1 of $\mathrm{P}_{2} \mathrm{O}_{5}=23 \mathrm{mg} \mathrm{dm}^{-3}$ of $\mathrm{P}$ ) was recommended according to CQFS-RS/SC (2004) for the treatments, except for the level 0 dag $\mathrm{kg}^{-1}$ of $\mathrm{P}$. When this dose was recommended from the level $0.436 \mathrm{dag} \mathrm{kg}^{-1}$ of $\mathrm{P}$, unconditionally the source of $\mathrm{P}$ added, a maximun dose of $10.500 \mathrm{~kg} \mathrm{ha}^{-1}$ of the mixture $\mathrm{P}+$ alkaline biosolid was generated. Thus, a dose of $10.500 \mathrm{~kg} \mathrm{ha}^{-1}$ of pure alkaline biosolid was taken as specific control $(0$ dag $\mathrm{kg}^{-1}$ of P) for each level of $\mathrm{P}$ added. Four levels and three

Table 1. Physical ${ }^{1}$ and chemical ${ }^{2}$ characteristics of a distrophic Red-Yellow Lato sol from Contenda, Paraná State, Brazil

\begin{tabular}{|c|c|c|c|c|c|c|c|c|c|c|c|}
\hline \multicolumn{3}{|c|}{ Physical characteristics } & \multicolumn{9}{|c|}{ Chemical characteristics } \\
\hline Sand & Silt & Clay & \multirow{2}{*}{$\mathrm{pH}\left(\mathrm{CaCl}_{2}\right)$} & $\mathrm{Ca}^{2+}$ & $\mathrm{Mg}^{2+}$ & $\mathrm{K}^{+}$ & $\mathrm{Al}^{3+}$ & $\mathrm{H}+\mathrm{Al}$ & $T$ & \multirow{2}{*}{$\begin{array}{c}P \\
\mathrm{mg} \mathrm{dm}^{-3}\end{array}$} & \multirow{2}{*}{$\begin{array}{c}\mathrm{C} \\
\mathrm{g} \mathrm{kg}\end{array}$} \\
\hline & $\mathrm{g} \mathrm{kg}^{-1}$ & & & \multicolumn{6}{|c|}{$\mathrm{cmol}_{\mathrm{c}} \mathrm{dm}^{-3}$} & & \\
\hline 182 & 193 & 625 & 3.9 & 1.0 & 0.6 & 0.15 & 2.5 & 12.1 & 13.8 & 1.5 & 31.7 \\
\hline
\end{tabular}

${ }^{1}$ EMBRAPA (1997); ${ }^{2}$ Pavan et al. (1992) 
Table 2. Agronomic characteristics of al kaline biosolid from the Belém Sewage Sludge Treatment Station, Curitiba, Paraná State, Brazil

\begin{tabular}{|c|c|c|c|c|c|c|c|c|c|c|}
\hline \multirow{2}{*}{$\begin{array}{c}\mathrm{pH} \\
\mathrm{CaCl}_{2}\end{array}$} & $\mathrm{ECaCO}_{3}$ & TN & $\mathbf{N}$ & $\mathrm{P}_{2} \mathrm{O}_{5}$ & $\mathbf{P}$ & $\mathrm{K}_{2} \mathrm{O}$ & 5 & $\mathrm{Ca}$ & $\mathrm{Mg}$ & $\mathrm{C}$ \\
\hline & \multicolumn{2}{|c|}{$\%$} & \multicolumn{8}{|c|}{$\mathrm{g} \mathrm{kg}^{-1}$} \\
\hline 12.8 & 93.38 & 67.54 & 4.9 & 3.47 & 0.151 & 1.0 & 1.0 & 193 & 111 & 31.1 \\
\hline
\end{tabular}

Table 3. Phosphorus concentration and granulometric fractions of partially acidulated phosphate rock (PAP), single superphosphate (SSP) and triple superphosphate (TSP)

\begin{tabular}{|c|c|c|c|c|c|c|c|c|c|c|c|}
\hline \multirow{3}{*}{$S P A^{(1)}$} & $\mathbf{P}^{(2)}$ & $\mathrm{P}_{2} \mathrm{O}_{5}{ }^{(3)}$ & $\mathrm{P}_{2} \mathrm{O}_{5} \mathrm{CNA}+\mathrm{H}_{2} \mathrm{O}^{(4)}$ & $\mathrm{P}_{2} \mathrm{O}_{5} \mathrm{H}_{2} \mathrm{O}^{(5)}$ & \multicolumn{7}{|c|}{ Granulometric fractions (mm) } \\
\hline & \multirow{2}{*}{\multicolumn{4}{|c|}{$\mathrm{g} \mathrm{kg}^{-1}$}} & 0.075 & 0.1 & 0.25 & 0.5 & 1 & 2 & 4 \\
\hline & & & & & \multicolumn{7}{|c|}{$\left(\mathrm{g} \mathrm{kg}^{-1}\right)^{(6)}$} \\
\hline $\operatorname{PAP}^{(7)}$ & 84.3 & $193.4^{(7)}$ & 148.2 & 63.4 & 65.7 & 213.1 & 172.1 & 180.6 & 165.6 & 5.8 & 0 \\
\hline $\operatorname{SSP}^{(8)}$ & 64.2 & $147.4^{(7)}$ & 128.9 & 92.2 & 0 & 0 & 0 & 0.1 & 103.1 & 876.5 & 20.3 \\
\hline $\operatorname{TSP}^{(9)}$ & 195.1 & 447.0 & 441.5 & 400.4 & 0 & 0 & 0 & 0 & 2.2 & 846.7 & 150.2 \\
\hline
\end{tabular}

${ }^{1} \mathrm{SP}$ : source of phosphorus added to alkaline biosolid; ${ }^{2} \mathrm{P}$ : phosphorus concentration in the sources analised by the Blue of phosphomolibdate method preceded by the nitroperchloric digestion (J ones \& Case, 1990); ${ }^{3} \mathrm{P}_{2} \mathrm{O}_{5}$ : total $\mathrm{P}_{2} \mathrm{O}_{5}$ concentration in the source; ${ }^{4} \mathrm{P}_{2} \mathrm{O}_{5} \mathrm{CNA}+\mathrm{H}_{2} \mathrm{O}$ : soluble $\mathrm{P}_{2} \mathrm{O}_{5}$ in neutrum amonium citrate + water $\left(\mathrm{Brasil}\right.$, 1988); ${ }^{5} \mathrm{P}_{2} \mathrm{O}_{5} \mathrm{H}_{2} \mathrm{O}: \mathrm{P}_{2} \mathrm{O}_{5}$ water soluble $(\mathrm{Brasil}$, 1988); ${ }^{6} \mathrm{~g} \mathrm{~kg}^{-1}$ : granulometric fraction retained in the mesh, in $\mathrm{g} \mathrm{kg}^{-1}$ (Brasil, 1983); ${ }^{7}$ PAP - partially acidulated phosphate rock Alvorada; ${ }^{8}$ SSP - single superphosphate; ${ }^{9} \mathrm{TSP}^{2}$ - ${ }^{2}$ triple superphos phate

sources of $\mathrm{P}$ added were generated, totalizing twelve treatments and four replicates. Therefore, the only causes of variation were level and source of $\mathrm{P}$ added.

The mixtures of the alkaline biosolid + sources of $\mathrm{P}$, by one hectare (2 x 106 average $\mathrm{kg}$ of the soil arable layer) to supply $45.85 \mathrm{~kg} \mathrm{ha}^{-1}$ of $\mathrm{P}$ were calculated for recepients of $3 \mathrm{dm}^{3}$ containing $2.5 \mathrm{~kg}$ of dry soil which were weighed on a precision balance (Table 4). The soil density of $1.070 \mathrm{~g} \mathrm{~cm}^{-3}$ according EMBRAPA (1997) was considered $1.000 \mathrm{~g} \mathrm{~cm}^{-3}$ for purpose of phosphorus recommendation.

The treatments were applied to the soil which were mixed and watered until its water retention capacity. Six plants of common bean (cv. IPR Uirapuru) were cultivated in each recepient.

The fertilization with nitrogen and potassium were recommended by hectare and calculated for recepients and

Table 4. Total doses, per recipient, of alkal ine biosolid added by phosphorus, amount of phosphorus sources and pure alkaline biosolid in the mixture for the establishment of treatments

\begin{tabular}{|c|c|c|c|c|c|c|}
\hline \multirow{2}{*}{$\mathbf{T}$} & \multirow{2}{*}{ SPA } & \multirow{2}{*}{$\begin{array}{c}\text { LPA } \\
\left(\text { dag kg }^{-1}\right)\end{array}$} & TD & PAB & QS & DP \\
\hline & & & \multicolumn{4}{|c|}{$\left(\right.$ g vase $\left.^{-1}\right)$} \\
\hline 1 & PAP & 0.000 & 13.125 & 13.125 & 0.000 & 0.000 \\
\hline 2 & PAP & 0.436 & 13.125 & 12.445 & 0.680 & 0.057 \\
\hline 3 & PAP & 0.872 & 6.563 & 5.883 & 0.680 & 0.057 \\
\hline 4 & PAP & 1.745 & 3.281 & 2.612 & 0.680 & 0.057 \\
\hline 5 & SSP & 0.000 & 13.125 & 13.125 & 0.000 & 0.000 \\
\hline 6 & SSP & 0.436 & 13.125 & 12.235 & 0.890 & 0.057 \\
\hline 7 & SSP & 0.872 & 6.563 & 5.673 & 0.890 & 0.057 \\
\hline 8 & SSP & 1.745 & 3.281 & 2.391 & 0.890 & 0.057 \\
\hline 9 & TSP & 0.000 & 13.125 & 13.125 & 0.000 & 0.000 \\
\hline 10 & TSP & 0.436 & 13.125 & 12.831 & 0.294 & 0.057 \\
\hline 11 & TSP & 0.872 & 6.563 & 6.269 & 0.294 & 0.057 \\
\hline 12 & TSP & 1.745 & 3.281 & 2.987 & 0.294 & 0.057 \\
\hline
\end{tabular}

T: treatment: SPA - Source of phosphorus added to alkaline biosolid; PAP - Partially acidulated phosphate rock Alvorada; SSP - Single superphos phate; TSP - Triple superphosphate: LPA - Leve of phos phorus added to alkaline biosolid; TD - Total dose, per recipient, of alkaline biosolid added by phos phorus (considered a soil density $=1.000 \mathrm{~g} \mathrm{~cm}^{-3}$ ); PAB - Quantity of pure alkaline biosolid in the mixture of phosphorus added; $\mathrm{QS}$ - Quantity of phos phorus source in the mixture of $\mathrm{P}$ added to supply the test-dose of $45.85 \mathrm{~kg}$ of $\mathrm{P}\left(105 \mathrm{~kg} \mathrm{ha}^{-1}\right.$ of $\mathrm{P}_{2} \mathrm{O}_{5}$ ) recommended for $1.0 \mathrm{ha}^{-1}(2000000 \mathrm{~kg}$ soil of the first $20 \mathrm{~cm}$ of soil) from each treatment (considered a soil density $=1.000 \mathrm{~g} \mathrm{~cm}^{-3}$ ),

DP - Dose of phosphorus recommended for one hectare $(2000000 \mathrm{~kg}$ of the first $20 \mathrm{~cm}$ of soil), equivalent to $105 \mathrm{~kg} \mathrm{ha}^{-1}$ of $\mathrm{P}_{2} \mathrm{O}_{5}$ considered a soil density of $1.000 \mathrm{~g} \mathrm{~cm}^{-3}$ ) added, homogeneously, in the soil surface 13 days after the seed germination.

At 95 days after sowing the harvest of aerial part of bean plants was done using a garden scissors at a $0.5 \mathrm{~cm}$ height from the soil level. This fresh material was dried an oven at 65 ${ }^{\circ} \mathrm{C}$ till constant weight. The total dry mass productivity of aerial part of bean plants (TDM), g recepient ${ }^{-1}$, was obtained by weight of stem + stalk + leaves + grains on a precision balance. The grain productivity, $g$ recepient ${ }^{-1}$, was obtained by weighing of grains on a precision balance after threshing it, manually.

After plant harvest composted soil sample (from the six single samples) of each experimental unit were collected for the analysis of extractable P Mehlich-1 analysis according to Pavan et al. (1992). The $P$ concentration in plant tissue was determined by the method of Blue of phosphomolibdate suggested by the same authors. This $P$ concentration was used for the calculation of accumulated $\mathrm{P}$ in the dry mass of bean plants according the following equation:

$$
\mathrm{AP}=\mathrm{PTDM} \times \mathrm{TDM}
$$

being:

AP - accumulated phosphorus, $\mathrm{g}$ recepient ${ }^{-1}$

PTDM - phosphorus concentration in the total dry mass of bean plants, $\mathrm{g} \mathrm{kg}^{-1}$

TDM - total dry mass productivity of the aerial part of bean plants, $\mathrm{g}$ recepient ${ }^{-1}$

The experimental design was completely randomized 4 by 3 . The homogeneity of variance was checked by the Bartlett's test and the mean comparison was carried out by the Tukey's test $(\mathrm{p}<0.05)$ using the software MStatc (Michigan State University). Tendency curves were generated with the aim of observing the correlation between the evaluated variables.

The relative agronomic effectiveness index (AEI) was generated according to Chien et al. (1990):

$$
\mathrm{AEI}=\left(\frac{\mathrm{Yn}}{\mathrm{Y}_{2}}\right) \times 100
$$


where:

AEI- Relative agronomic effectiveness index, $\%$

Yn - Total dry mass production of aerial part of bean plants obtained with the treatments related to the levels of $0.436,0.872$, $1.745 \mathrm{dag} \mathrm{kg}^{-1}$ of P added (PAP and SSP) to alkaline biosolid;

$\mathrm{Y}_{2}$ - Total dry mass production of aerial part of bean plants obtained with the treatments related to the levels of $0.436,0.872$, $1.745 \mathrm{dag} \mathrm{kg}^{-1}$ of $\mathrm{P}$ added from the triple superphosphate, taken as a reference source of $\mathrm{P}$ added to alkaline biosolid.

\section{RESULTS AND DISCUSSION}

The analysis of variance of extractable P Mehlich-1, accumulated $P$, grain and total dry mass production of aerial part of bean plants can be found in the Table 5 .

Table 5. Analysis of variance for the data of extractable phosphorus M ehlich-1 and accumulated phosphorus in dry mass of bean plants

\begin{tabular}{|c|c|c|c|c|c|}
\hline \multirow{2}{*}{$\begin{array}{c}\text { Cause } \\
\text { of variation }\end{array}$} & \multirow{2}{*}{ DF } & \multirow{2}{*}{$\begin{array}{l}\text { P Mehlich-1 } \\
\left(\mathrm{mg} \mathrm{dm}^{-3}\right)\end{array}$} & \multirow{2}{*}{$\begin{array}{c}\text { AP } \\
\left(\operatorname{dag} \mathbf{k g}^{-1}\right)\end{array}$} & GP & TDM \\
\hline & & & & \multicolumn{2}{|c|}{ (g recipient ${ }^{-1}$ ) } \\
\hline LPA & 3 & $24.392 * *$ & $0.350 * *$ & $1.392^{* *}$ & $5.614 * *$ \\
\hline SPA & 2 & $12.159 * *$ & $0.074^{\text {ns }}$ & $3.477^{*} *$ & $7.001 * *$ \\
\hline$L \times S$ & 6 & $5.524 * *$ & $0.021^{\text {ns }}$ & $0.314^{*}$ & $0.402^{\text {ns }}$ \\
\hline Error & 36 & 0.277 & 0.014 & 0.102 & 0.666 \\
\hline CV (\%) & & 7.75 & 32.19 & 21.92 & 19.36 \\
\hline DMS & & 0.235 & 0.011 & 0.086 & 0.566 \\
\hline
\end{tabular}

** significant at level of 0,01 of probability; ${ }^{*}$ significant at level of 0,05 probability; ns - not significant; DF - Degrees of freedom; AP - accumulated phosphorus in dry mass of bean plants ( $g$ recipient ${ }^{1}$ ); GP - grain production ( g recipient $^{-1}$ ); LPA - level of phosphorus added; SPA - source of phosphorus added; $\mathrm{L} \times \mathrm{S}$ - interaction between the factors level and source of phos phorus added; $\mathrm{CV}(\%)$ - coefficient of variation, in percentage; LSD - least significant difference by Bartlett's test

\section{Soil phosphorus Mehlich-1 and accumulated phosphorus}

Interaction between the level and source of $\mathrm{P}$ added to alkaline biosolid was not significant $(\mathrm{p}>0.05)$ for the extractable P Mehlich-1. All the treatments increased the values of this variable compared to the initial soil concentration and the values verified in the control treatment $(0 \% \mathrm{P})$. The averages show that in comparison to the dose of $45.85 \mathrm{~kg} \mathrm{ha}^{-1}$ of $\mathrm{P}\left(23 \mathrm{mg} \mathrm{dm}^{-}\right.$ ${ }^{3}$ of $\mathrm{P}$ ) the treatments referring to the level $0.436 \% \mathrm{P}$ from PAP $\left(10.725 \mathrm{mg} \mathrm{dm}^{-3}\right.$ of $\mathrm{P}$ or a recovery about $46 \%$ ) and $0.872 \% \mathrm{P}$ from the SSP $\left(8.775 \mathrm{mg} \mathrm{dm}^{-3}\right.$ of $\mathrm{P}$ or a recovery about $\left.38 \%\right)$ were superior to the control $(0 \% \mathrm{P})$ and the other treatments from the same sources (Table 6).

Table 6. Comparison of averages of extractable phosphorus Mehlich-1 according to the source of phosphorus added to alkaline biosolid

\begin{tabular}{ccccc}
\hline & \multicolumn{4}{c}{ LPA (\%) } \\
\cline { 2 - 5 } SPA & $\mathbf{0}$ & $\mathbf{0 . 4 3 6}$ & $\mathbf{0 . 8 7 2}$ & $\mathbf{1 . 7 4 5}$ \\
\cline { 2 - 5 } & \multicolumn{4}{c}{ P Mehlich-1 $\mathbf{( \mathbf { m g ~ d m } ^ { - 3 } )}$} \\
PAP & $5.425 \mathrm{a}$ & $10.725 \mathrm{a}$ & $7.900 \mathrm{a}$ & $6.400 \mathrm{a}$ \\
SSP & $4.750 \mathrm{a}$ & $7.225 \mathrm{~b}$ & $8.775 \mathrm{a}$ & $6.725 \mathrm{a}$ \\
TSP & $4.575 \mathrm{a}$ & $6.275 \mathrm{c}$ & $6.450 \mathrm{~b}$ & $6.225 \mathrm{a}$ \\
\hline
\end{tabular}

Note - Mean followed by the same letter to not differ among each other by the Tuckey's test at the level of 0,05 probability; LPA (\%) - level of phosphorus added, in percentage; SPA - source of phosphorus added; PAP - partially acidulated phosphate rock Alvorada; SSP - single superphosphate; TSP - triple superphosphate
Silva et al. (2001) applied increasing doses of sewage sludge in soil and, despite the fact that they were applied separately to mineral phosphorus sources, they found very similar results to those obtained in the present work. The results obtained by Chueiri et al. (2007) showed that the increasing doses of alkaline biosolid added to mineral phosphorus fertilization, despite the high initial soil $\mathrm{P}$ concentration, resulting in a linear increase in the extractable $\mathrm{P}$ (Mehlich-1). These authors attributed the fact to the high values of soil $\mathrm{pH}$ occasioned by the incubation of alkaline biosolid during 20 days which should have solubilized the nutrient and increased the values of extractable P. However, it must be considered that these results may be due to the extractant used which extracted both the available and the unavailable soil P (Novais \& Smith, 1999). In this work there was no incubation but it seems the time spent during the bean plant growth was enough to provide the very similar results.

These results were adjusted to a quadratic model (Figure 1) and showed that extractable $\mathrm{P}$ tends to decrease concomitantly to the increasing levels of P added from the SSP and TSP and consequently reduction of quantities of pure alkaline biosolid in mixtures (Table 4). The same result was observed for the source PAP but with a different adjustment to the model specified above $\left(\mathrm{R}^{2}=0.53^{* *}\right)$.

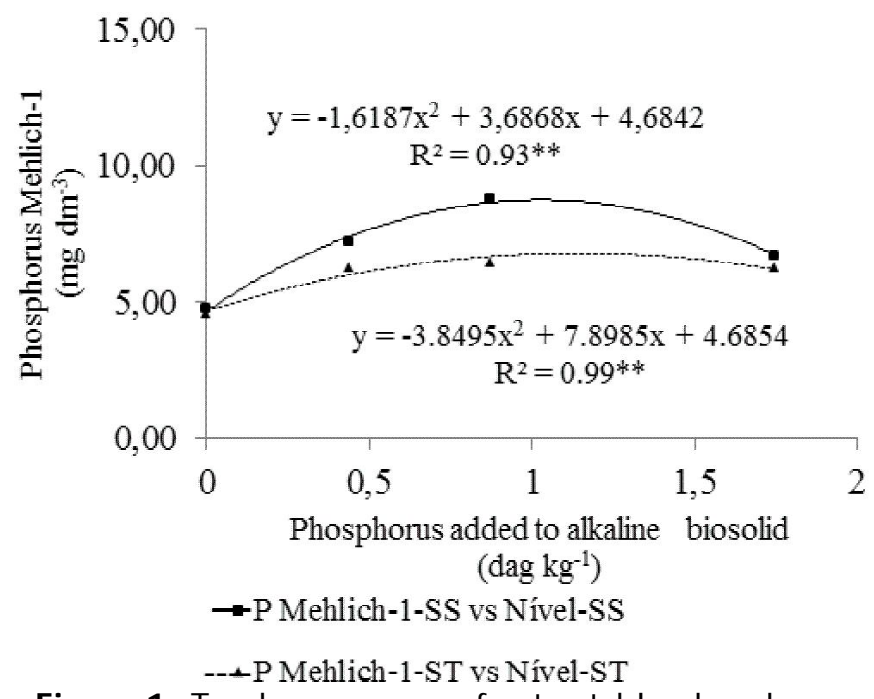

Figure 1. Tendency curves of extractable phosphorus M ehlich-1 according the level of phosphorus added to alkaline biosolid from the partially acidulated phosphate rock Alvorada (LPA-PAP), single superphosphate (LPASSP) and triple superphosphate (LPA-TSP)

The values of extractable $\mathrm{P}$, even for the best treatments, may have been overestimated due to the low efficiency of $P$ extraction by the acid extractant Mehlich-1 in soils with high content of clays and iron $(\mathrm{Fe})$ and aluminum $(\mathrm{Al})$ oxides and hydroxides (CQFS-SC/RS, 2004). This fact must be due to the extraction of $\mathrm{P}$ from the low solubility compounds formed from the reaction between soluble $\mathrm{P}$ and $\mathrm{Ca}$ in the high $\mathrm{pH}$ condition into the biosolid used.

Anyway, the P concentrations verified here were adequate, respectively, in the levels very high and average for bean according to Fageria (1998), and from low values for the controls 
to very high values for the best treatments according to CQFSSC/RS (2004).

Among the factors which may also have corroborated with these results is the high concentration of water soluble $\mathrm{P}$ present in the PAP (Table 3). Partially acidulated phosphate rocks have, at least, 5\% of total water soluble $\mathrm{P}$ and $9 \%$ of soluble P in CNA + water (CQFS-SC/RS, 2004), and may rapidly increase the extractable P Mehlich-1 (Novais \& Smith, 1999). The PAP has a thin granulometry and its non-acidulated fraction (reactive rock phosphate Alvorada) can be dissolved due to the extremely acidic soil $\mathrm{pH}$, initially, and consequently, promote the releasing of those insoluble $\mathrm{P}$ fraction to the soil solution (Novais \& Smith, 1999).

The higher doses of alkaline biosolid present in the mixtures (levels 0.436 and $0.872 \mathrm{dag} \mathrm{kg}^{-1}$ of P) (Table 3), which had about $0.151 \mathrm{dag} \mathrm{kg}^{-1}$ of total $\mathrm{P}$ in its original composition, can also explain these results. According to SANEPAR (1997) about $50 \%$ of the total organic P present in these biosolids can be mineralized in the first year application.

It is possible that: the soluble $\mathrm{P}$ concentration present in the SSP also contributed with these results. This $\mathrm{P}$ source has about $16 \%$ of water soluble P(CQFS-SC/RS, 2004 and Table 3). Its granulated form made possible the lesser contact with the soil particles and, consequently, less soil P retention occured. The physical nature of this $\mathrm{P}$ source is also propitious to its uniform dispersion in the soil volume, making it even more favorable to a better soil sampling necessary for the $\mathrm{P}$ analysis and the obtention of coherent results.

Just the level of $\mathrm{P}$ added was significant $(\mathrm{p}<0.01)$ in relation to the accumulated $\mathrm{P}$ in dry mass of bean plants. All the treatments increased the accumulated $P$, showing equivalence between each other and superior to the specific controls $(0$ dag $\mathrm{kg}^{-1}$ of P).

A high correlation between accumulated $\mathrm{P}$ and level of $\mathrm{P}$ added is shown by the quadratic model observed in the Figure 2. This fact showed the tendency of increase in the $P$ accumulation since the average of accumulated $\mathrm{P}$ for the controls till the levels 0.436 and $0.872 \mathrm{dag} \mathrm{kg}^{-1}$ of $\mathrm{P}$ and then decreasing, steeply.

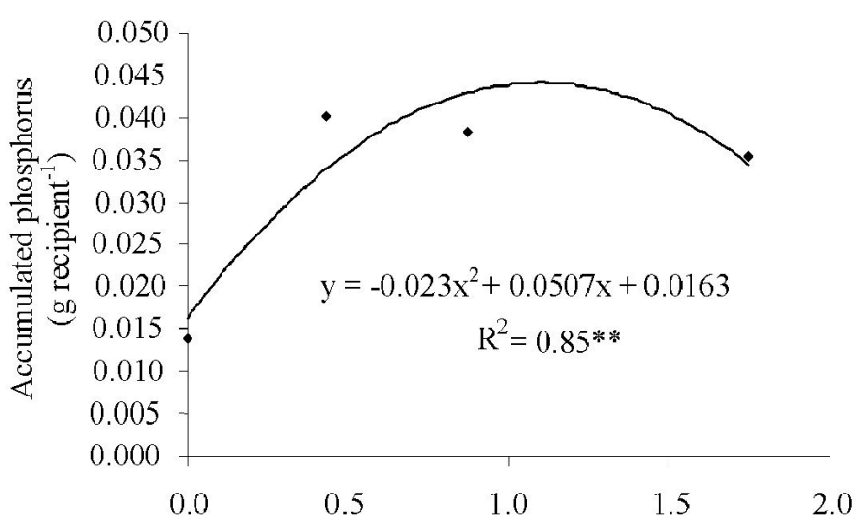

Phosphorus added to alkaline biosolid (dag $\mathrm{kg}^{-1}$ )

Figure 2. Tendency curves of the average accumulated phosphorus according the level of phosphorus added to the alkaline biosolid
The percentages of accumulated $\mathrm{P}$ varied from 0.035 $\mathrm{g} \mathrm{recepient}^{-1}\left(0.78 \mathrm{dag} \mathrm{kg}^{-1}\right)$ to $0.040 \mathrm{~g} \mathrm{recepient}^{-1}\left(0.85 \mathrm{dag} \mathrm{kg}^{-1}\right)$ and were above the average values normally considered ideal in bean plant tissue $\left(0.1 \mathrm{dag} \mathrm{kg}^{-1}\right.$, equivalent to 0.0045 $\mathrm{g}$ recepient ${ }^{-1}$ to $0.5 \mathrm{dag} \mathrm{kg}^{-1}$, equivalent to $0.023 \mathrm{~g} \mathrm{recepient}^{-1}$ ). However, one must consider the well-established data which show that the bean plants when grown in the greenhouse accumulate more $\mathrm{P}$ compared with plants grown in field conditions.

These facts occurred probably due to the fact that the available $\mathrm{P}$, in recepients, has more contact with the plant root and so, is more accessible for the uptake by the plant root system. Also according to Fageria (1998) there are groups of bean genotypes which cannot provide answer to high $\mathrm{P}$ accumulation because they absorb higher quantities of $\mathrm{P}$ but shows no increase in the biomass production. The cultivar used in this work, probably, belongs to one of these genotype groups.

The following factors also must have contributed with these results: i) The increase of soil total $\mathrm{P}$ (Table 6); ii) The total $\mathrm{Ca}$ and $\mathrm{Mg}$ concentrations present in the alkaline biosolid used in the mixtures which may have dissolved in the acid soil environment with the consequent releasing of these nutrients to the soil solution. The value of the quotient between exchangeable $\mathrm{Ca}$ and $\mathrm{Mg}$ in the soil were 1.7:1,0. This value was below 2:1 and 3:1 verified by Hernandez \& Silveira (1998) considered the more propitious to the equilibrium among all soil nutrients and favorable to the higher $\mathrm{P}$ absorption by the corn in the field condition. It's also needs to be considered that the absorption of $\mathrm{H}_{2} \mathrm{PO}_{4}^{-}$is maximun when the $\mathrm{Mg}$ is available in adequate concentration on the root surface (Malavolta, 2006).

\section{Grain and total dry mass production}

There were significant effect of the interaction level and source of $\mathrm{P}$ added in relation to the common bean grain production $(\mathrm{p}<0.05)$. The Figure 3 indicates that the levels

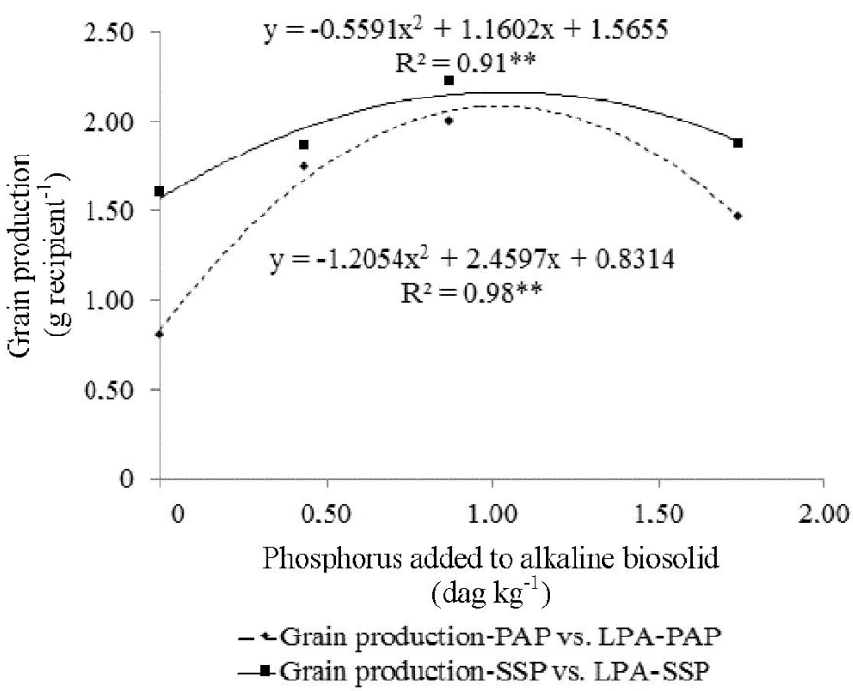

Figure 3. Tendency curves of grain production according to the level of phosphorus added to alkaline biosolid from the partially acidulated phosphate rock Alvorada (G rain production-PAP vS. LPA-PAP) and single superphosphate (grain production-SSP vS. LPA-SSP) 
0.436 and $0.872 \%$ P from the PAP and SSP provided, numerically, the best production, showing superiority to the average of controls.

The best production provided by the TSP was obtained by the level of $0.436 \% \mathrm{P}$ in comparison to the control and the other levels of $\mathrm{P}$ added from the same source. These results were ratified by the high coefficient of determination for grain production according to the level of phosphorus added from the PAP and SSP. and the low correlation verified for $\mathrm{TSP}\left(\mathrm{R}^{2}=\right.$ $0.27 * *)$.

According to these results it is possible to conjecture that the pure alkaline biosolid in the mixtures may have exerted influence upon the grain productivity by possessing small amounts of macro and micronutrients in its composition (Logan \& Harrison, 1995). So, the quantities of this alkaline biosolid like those present at the level $0.436 \% \mathrm{P}$ (about $10 \mathrm{Mg}$ ) may be used in mixtures with $\mathrm{P}$ sources. The high quadratic correlation verified for grain production with the soil P for PAP (Figure 4) indicates a decrease in the bean grain production according to the extractable P provided by the level $0.872 \%$.

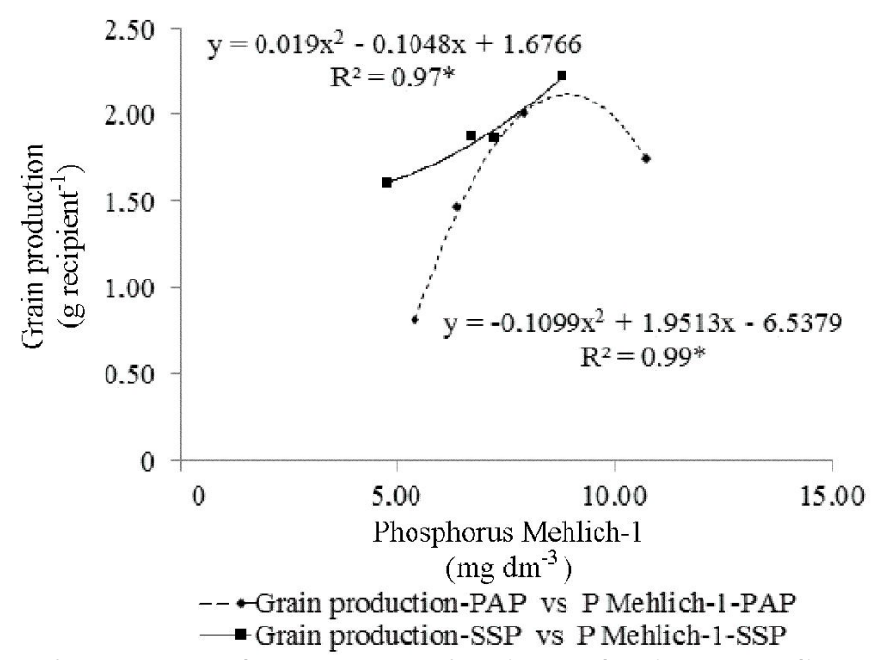

Figure 4. Tendency curves of grain production according to the level of phosphorus added to alkaline biosolid from the partially acidulated phosphate rock Alvorada (grain production-PAP vs. LPA-PAP) and single superphosphate (grain production-LPA vs. LPA-SSP)

For SSP, the quadratic closed correlation indicates that, with the increase in the extractable $\mathrm{P}$ the grain production increases concomitantly. The PAP and the SSP has a less gross granulometry than the TSP $\left(\mathrm{R}^{2}=0.49 *\right)$ and cover a larger soil volume making it more accessible to the root system. As a consequence, this absorbed $\mathrm{P}$ was enough to produce a larger grain production in comparison the lesser levels of phosphorus added.

These results may still be explained by the possible provision of the other nutrients and the organic $\mathrm{P}$ released from the alkaline biosolid (SANEPAR, 1997) present in the mixtures which provided the better production (Logan \& Harrison, 1995). According to these results higher doses of sewage sludge allied to $\mathrm{P}$ fertilization have provided better production for soybean (Vieira et al., 2005) and corn (Silva et al., 2002). For Lourenço et al. (1996) the application of increasing doses of sewage sludge to agricultural soils leads to increase in both nutrient absorption and productivity of common bean, corn and mimosa. These occurrences also corroborate with the present results despite the fact that those biosolids were applied separately from the phosphated mineral fertilization.

Level and source of $\mathrm{P}$ added showed independence between each other $(\mathrm{p}<0.01)$ in relation to the dry mass production of bean plants. The total dry mass production was highly correlated with the level of $\mathrm{P}$ added and obeyed a quadratic model (Figure 5), indicating a decreasing trend in the dry mass production beyond a certain limite $\left(1.25 \mathrm{dag} \mathrm{kg}^{-1}\right)$ of the level of $\mathrm{P}$ added. This fact may be due to the presence of higher quantities of alkaline biosolid in the mixtures which must have provided other macro and micronutrients present in its composition (Logan \& Harrison, 1995 and Table 2).

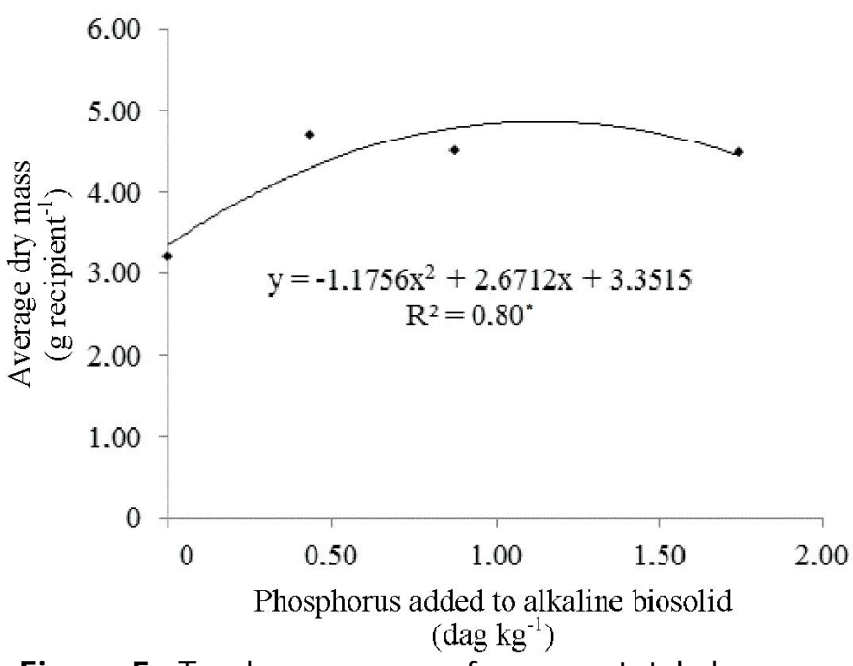

Figure 5. Tendency curves of average total dry mass production according the level of phosphorus added to alkaline biosolid

The SSP was the better $\mathrm{P}$ source added in relation to dry mass production of bean plants (Table 7). The fact is probably due to the less gross granulometry which made it more accessible to the plant roots and the presence of small quantities of sulphur and micronutrients in its minimum composition (Brasil, 1983; Malavolta, 2006).

The total dry mass production of bean presented a positive correlation with the accumulated $\mathrm{P}$. This fact indicates that the

Table 7. Average comparison of total dry mass production according to the source of phosphorus added to alkaline biosolid

\begin{tabular}{cccccc}
\hline & \multicolumn{5}{c}{ LPA (\%) } \\
\cline { 2 - 6 } SPA & $\mathbf{0}$ & $\mathbf{0 . 4 3 6}$ & $\mathbf{0 . 8 7 2}$ & $\mathbf{1 . 7 4 5}$ & Mean \\
\cline { 2 - 5 } & \multicolumn{5}{c}{ Total dry mass (g recipient ${ }^{-1}$ ) } \\
PAP & 2.982 & 4.263 & 4.565 & 4.345 & $4.039 \mathrm{~b}$ \\
SSP & 3.805 & 5.280 & 5.388 & 5.320 & $4.948 \mathrm{a}$ \\
TSP & 2.815 & 4.540 & 3.505 & 3.785 & $3.661 \mathrm{~b}$ \\
\hline
\end{tabular}

Note: Average followed by the same word not differ among each other by the Tukey's test at level of 0,05 probability; LPA (\%) - Level of phosphorus added, in percentage; SPA - Source of phosphorus added; PAP - Partially acidulated phosphate rock Alvorada; SSP - Single superphos phate; TSP triple superphosphate 
increase in accumulated $\mathrm{P}$ in plant tissue is concomitant to the increasing of dry mass production (Figure 6). Similar results were also verified in the work developed by Zapata \& Zaharah (2002) which showed that a mixture of sewage sludge + triple superphosphate at the levels of 50 and $150 \mathrm{mg} \mathrm{kg}^{-1}$ of $\mathrm{P}$ provided the greater quantities of wheat dry mass in comparison to the triple superphosphate alone. Increases in the dry mass production were observed, particularly, with the treatment containing the high dose of sewage sludge. The best source of $\mathrm{P}$ added for dry mass production was SSP according the results in the Table 7.

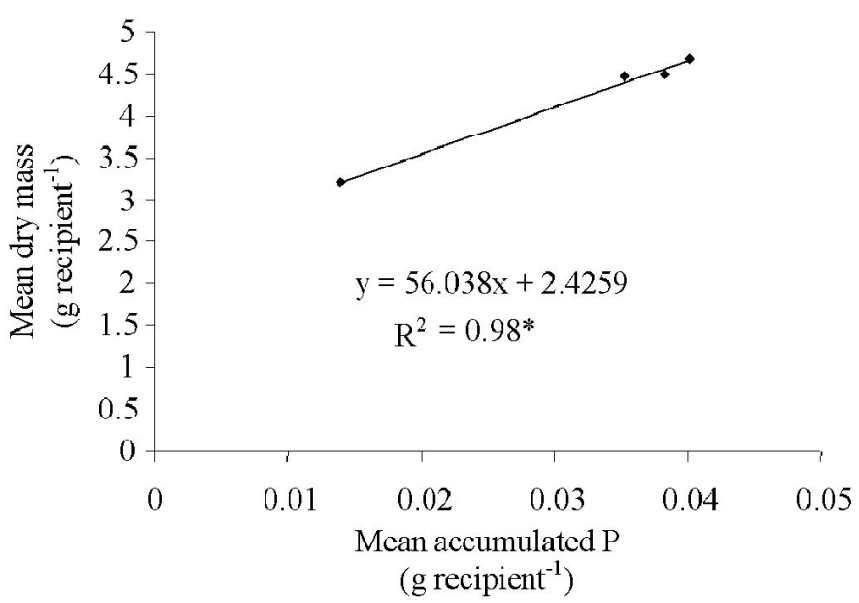

Figure 6. Tendency curves of total average dry mass production according to the average accumulated phosphorus for bean plants

\section{Relative agronomic effectiveness index}

The relative agronomic effectiveness index (AEI) increased concomitantly with the increasing of level of $\mathrm{P}$ added. The Table 8 shows that the indices also increased at the same time that there was an increase in the dry mass production obtained with the tested sources and decreased with the treatments from the reference source (TSP).

Table 8. Relative agronomic effectiveness index for the level of phosphorus added to alkaline biosolid from the single superphosphate and partially acidulated phosphate rock Alvorada

\begin{tabular}{|c|c|c|c|c|c|}
\hline \multirow{2}{*}{$\begin{array}{l}\text { LPA } \\
(\%)\end{array}$} & TDM/TSP & TDM/SSP & \multirow{2}{*}{$\begin{array}{c}\text { AEI-SSP } \\
(\%)\end{array}$} & \multirow{2}{*}{$\begin{array}{c}\text { TDM/PAP } \\
\text { (g recipient }^{-1} \text { ) }\end{array}$} & \multirow{2}{*}{$\begin{array}{c}\text { AEI-PAP } \\
(\%)\end{array}$} \\
\hline & \multicolumn{2}{|c|}{ (g recipient ${ }^{-1}$ ) } & & & \\
\hline 0.436 & 4.540 & 5.280 & 116.300 & 4.263 & 93.900 \\
\hline 0.872 & 3.505 & 5.388 & 153. & 4.565 & 130.000 \\
\hline 1.745 & 3.785 & 5.320 & 140.550 & 4.345 & 115.000 \\
\hline
\end{tabular}

LPA $(\%)$ - level of phosphorus added, in percentage; TDM/TSP( $\left(\right.$ recipient $\left.^{-1}\right)$ - total dry mass of bean plants produced by triple superphosphate; TDM/SSP $\left(\mathrm{g} \mathrm{recipient}^{-1}\right)$ - total dry mass of bean plants produced by single superphosphate; AEI-SSP (\%) - relative agronomic effectiveness index for single superphosphate; TDM/FPA ( $g$ recipient $t^{-1}$ - total dry mass of bean plants produced by partially acidulated phosphate rock Alvorada; AEI-FPA (\%) - relative agronomic effectiveness index for partially acidulated phosphate rock Alvorada

For that reason, the higher values observed for AEI is due to the increase of $\mathrm{P}$ added levels and are not also according to the higher production of total dry mass obtained with the checked sources but due to the decreasing of total dry mass production verified for the TSP used as the reference source to add $\mathrm{P}$ in alkaline biosolid. These facts indicate that there is a less efficiency of TSP as a source of P added to alkaline biosolid. According to these results, the best AEI was obtained with the level $0.436 \% \mathrm{P}$ from the SSP which provided a dry mass production $16.3 \%$ higher than the TSP.

Similar results occurred in relation to the total dry mass production obtained with the PAP. However, starting from the level $0.872 \% \mathrm{P}$ a decrease in the AEI value of about $15 \%$ was verified. Thus, the best level of $\mathrm{P}$ added from this source was $0.872 \% \mathrm{P}$ (Table 6) followed by the level of $0.436 \% \mathrm{P}$ which provided $15 \%$ more dry mass, without, however, providing a lesser production in comparison to the triple superphosphate.

\section{Conclusions}

1. The extractable phosphorus Mehlich-1 and its accumulation in bean plants increases for all the treatments.

2. The grain and total dry mass production of bean plants also increases for all the treatments.

3. The best level of phosphorus added to alkaline biosolid is $0.436 \% \mathrm{P}$ from the single superphosphate and partially acidulated phosphate rock Alvorada.

4. Single superphosphate and partially acidulated phosphate rock Alvorada are efficient sources to add phosphorus in alkaline biosolid considering the level $0.436 \%$.

\section{AKNOWLEDGEMENTS}

We specially thank to CAPES: for the scholarship provided for this study.

\section{LITERATURE CITED}

Bar-Tal, A.; Yermiyahu, U.; Beraud, J.; Keinan, M.; Rosenberg, D.; Zohar, D.; Rosen, V.; Fine, P. Nitrogen, phosphorus, and potassium uptake by wheat and their distribution in soil following successive, annual compost application. Journal of Environmental Quality, v.33, p.1855-1865, 2004.

Brasil. Leis, decretos, etc. Portaria n. 01, de 04 de mar. de 1983. Diário Oficial da União, Brasília, 09 de mar. de 1983.

Brasil. Ministério da Agricultura. Laboratório Nacional de Referencia Vegetal. Análise de corretivos, fertilizantes e inoculantes - LANARV: Métodos Oficiais. Portaria/ SNAD no 31/82, Imprensa Oficial, Brasília, 1988. 104p.

Chien, S. H.; Sale, P. W. G.; Friesen, D. K. A discussion of the methods for comparing the relative effectiveness of phosphate fertilizers varying in solubility. Fertilizer Research, v.24, p.149-157, 1990.

Christie, P.; Easson, D. L.; Picton, J. R.; Love, S. C. P. Agronomic value of alkaline-stabilized sewage biosolids for spring barley. Agronomy Journal, v.93, p.144-151, 2001.

CQFS-SC/RS - Comissão de Química e Fertilidade do Solo, Sociedade Brasileira de Ciência do Solo, Núcleo Regional Sul, 2004. 400p. 
Corrêa, R.S. Efficiency of five biosolids to supply nitrogen and phosphorus to ryegrass. Pesquisa Agropecuária Brasileira, v.39, p.1133-1139, 2004.

Chueiri, W. A.; Serrat, B. M.; Biele, J.; Favaretto, N. Lodo de esgoto e fertilizante mineral sobre parâmetros do solo e de plantas de trigo. Revista Brasileira de Engenharia Agrícola e Ambiental, v.11, p.502-508, 2007.

EMBRAPA - Empresa Brasileira de Pesquisa Agropecuária Centro Nacional de Pesquisa de Solos. Manual de métodos de análise física de solos. 2.ed. Rio de Janeiro, 1997. 212p.

EMBRAPA - Empresa Brasileira de Pesquisa Agropecuária Centro Nacional de Pesquisa de Solos. Sistema brasileiro de classificação de solos. Brasília, DF: Embrapa, 2006, 306p.

Fageria. N. K. Eficiência de uso de fósforo pelos genótipos de feijão. Revista Brasileira de Engenharia Agrícola e Ambiental, v.2, p.128-131, 1998.

Gomes. S. B. G. V.; Nascimento, C. W. A.; Biondi, C. M.; Accioly, A. M. A. Alterações químicas em argissolo tratado com lodo de esgoto, Revista Caatinga, v.18, p.185-194, 2005.

Guedes, M. C.; Andrade, C. A.; Poggiani, F.; Mattiazzo, M. E. Propriedades químicas do solo e nutrição do eucalipto em função da aplicação de lodo de esgoto. Revista Brasileira de Ciência do Solo, v.30, p.267-280, 2006.

Hernandez, R. J. M.; Silveira, R. I. Efeito da saturação por bases, relações $\mathrm{Ca}: \mathrm{Mg}$ no solo e níveis de fósforo sobre a produção de material seco e nutrição mineral de milho (Zea mays, L.). Scientia Agricola, v.55, p.79-85, 1998.

Logan, T. J.; Harrison, B. J. Physical characteristics of alkaline stabilized sewage sludge (N-Viro Soil) and their effects on soil physical properties. Journal of Environmental Quality, v.24, p.153-164, 1995.

Lourenço, R. S.; Anjos, A. R. M.; Medrado, M. J. S. Efeito do lodo de esgoto na produtividade de milho e feijão no sistema de produção de bracatinga. Sanare, v.5, p.90-92, 1996.

Malavolta, E. Manual de nutrição mineral de plantas. Piracicaba: Agronômica Ceres, 2006. 638p.

Nascimento, C. W. A.; Barros, D. A. S.; Melo, E. C.; Oliveira, A. B. Alterações químicas em solos e crescimento de milho e feijoeiro após aplicação de lodo de esgoto. Revista Brasileira de Ciência do Solo, v.28, p.385-392, 2004.

Novais, R. F.; Smith, T. J. Fósforo em solo e planta em condições tropicais. Viçosa: DPS/UFV, 1999. 399p.
Ostoics, E.; Csatho, T.; Nemeth, G.; Baczo, M. M.; Radminzinsk, L. Influence of phosphate fertilizer sources and soil properties on trace element concentrations of red clover. Communications in Soil Science and Plant Analysis, v.36, p.557-570, 2005.

Pavan, M. A.; Bloch, M. F.; Zempulski, H. C.; Miyazawa, M.; Zocaler, D. C. Manual de análise química de solo e controle de qualidade. Londrina: IAPAR, 1992. 40p.

SANEPAR - Companhia de Saneamento do Paraná. Manual técnico para utilização agrícola do lodo de esgoto no Paraná. Andreoli, C.V.; Fernandes, F. (Coords.), Curitiba, 1997. 96p.

Silva, F. C.; Boaretto, A. E.; Berton, R. S. Efeito de lodo de esgoto na fertilidade de um Argissolo Vermelho-Amarelo cultivado com cana de açúcar. Pesquisa Agropecuária Brasileira, v.36, p.831-840, 2001.

Silva, J. E.; Resck, D. V. S.; Sharma, R. D. Alternativa agronômica para o biossólido produzido no Distrito Federal. I - Efeito na produção de milho e adição de metais pesados em Latossolo no cerrado. Revista Brasileira de Ciência do Solo, v.26, p.487-495, 2002.

Silva, L.C. da; Lucchesi, L.A.C.; Koehler, H.S. Lodo de esgoto alcalinizado adicionado de fósforo aplicado num latossolo vermelho distrófico de Arapoti-PR, Scientia Agraria, v.11, p.393-405, 2010a.

Silva, L.C. da, Lucchesi, L. A. C., Koehler, H. S. Acidity variables and exchangeable calcium and magnesium on an oxisol treated with phosphate alkaline biosolid Scientia Agraria, v.11, p.331-342, 2010b.

Silva, L. C. da; Lucchesi, L. A. C.; Koehler, H. S. Attributes of acidity and exchangeable cátions in oxisol fertilized by phosphate alkaline biosolid, Scientia Agraria, v.12, p.41-51, 2011.

Vieira, R. F.; Tanaka, R. T.; Tsai, S. M.; Pérez, D. V.; Souza Silva, C. M. M. Disponibilidade de nutrientes no solo, qualidade de grãos e produtividade da soja em solo adubado com lodo de esgoto. Pesquisa Agropecuária Brasileira, v.40, p.919926, 2005.

Zapata, F.; Zaharah, A. R. Phosphorus availability from phosphate rock and sewage sludge as influenced by the addition of water soluble phosphate fertilizer. Nutrient Cycling in Agroecosystems, v.63, p.43-48, 2002. 